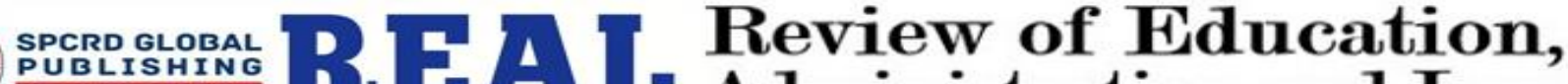 Administration and Law \\ Journal homepage: http://real.spcrd.org ISSN (Print): 2708-1788

\section{Awareness of Mainstream Primary School Teachers on the ADHD Symptoms in Punjab}

\author{
a Shaheen Pasha, ${ }^{\mathrm{b}}$ Maimona Ijaz, ${ }^{\mathrm{c}}$ Muhammad Ahmed Qadri \\ ${ }^{a}$ Chairperson, Department of Special Education, University of Education, Lahore, Pakistan \\ Email: drshaheen.pasha@ue.edu.pk \\ ${ }^{\mathrm{b}}$ Visiting Faculty Member, Department of Special Education, University of Education, Lahore, Pakistan \\ Email: fnm.international@gmail.com \\ ${ }^{\mathrm{c}}$ Former Dean Faculty of Arts and Social Sciences, University of Karachi, Pakistan \\ Email: Prof.qadri@gmail.com
}

\begin{tabular}{|c|c|}
\hline LE DETAILS & ABSTRACT \\
\hline & \multirow{11}{*}{$\begin{array}{l}\text { Attention deficit hyperactivity disorder (ADHD) harms the learning, } \\
\text { social, and family performance of the child as one of the most prevalent } \\
\text { psychological disorders of children. The recent rehabilitation activities } \\
\text { focused on schools with trained teachers. This study's key goal is to } \\
\text { investigate "Awareness Level of Primary School Teachers Regarding the } \\
\text { Symptoms of Students with ADHD in Mainstream Schools of Punjab". } \\
\text { The research has used the disability model presented in ICF by WHO } \\
\text { having five major areas of functional disorders of ADHD - Attention, } \\
\text { Hyperactive/ impulsive Oppositional Defiant Disorder, Cognitive } \\
\text { Symptoms, and Psychosocial Symptoms. A sample of } 440 \text { individuals } \\
\text { was selected from } 20 \text { schools. Teachers, parents, and psychologists were } \\
\text { the respondents as well. The data was collected from } 20 \text { schools of } \\
\text { Lahore city; and was analyzed by using a correlation between the } \\
\text { variables (psychological, behavioral, cognitive, psychosocial, symptoms } \\
\text { of ADHD). Frequencies and percentages were calculated for each of } 84 \\
\text { statements in five areas. Results showed most of the teachers have an } \\
\text { insufficient level of knowledge about ADHD. There is a tangible need for } \\
\text { training programs provided to the teachers about early recognition and } \\
\text { policy of care of ADHD children. }\end{array}$} \\
\hline & \\
\hline 22021 & \\
\hline & \\
\hline$n s$, & \\
\hline Psyc & \\
\hline Problems, Diagnc & \\
\hline & \\
\hline & \\
\hline I18 & \\
\hline DOI: $10.47067 /$ & \\
\hline
\end{tabular}

(C) 2021 The authors. Published by SPCRD Global Publishing. This is an open access article under the Creative Commons AttributionNonCommercial 4.0

Corresponding author's email address: Email: drshaheen.pasha@ue.edu.pk

\section{Introduction}

ADHD is among the most prevalent neurological disorders in children having symptoms of lack of interest (not focused), impulsivity (extra activity not appropriate for the environment), and emotional instability. ADHD is frequently detected for the first time in school children due to classroom disruptions or homework issues. ADHD is more common in school when teacher experiences these key 
symptoms related to behavioral issues in school for example children who do not follow the orders of a teacher, disturb classroom activities, play around their seats and social interaction problems with their peers(Drechsler et al., 2020).ADHD is diagnosed clinically by parent's observation in early childhood development and school by the teachers at the age of 5. Globally 3to 5 percent of children and adults are affected with $\mathrm{ADH}$ and more or less present in every classroom. This may result in delayed intervention through the lack of awareness among primary school teachers. (Alfageer et al., 2018).

A Child with an attention deficit or hyperactivity faces numerous social and academic challenges. It can be tough to get along with your classmates and colleagues. They find it difficult to pay attention in school, control their actions, and sometimes interfere with academic tasks. Parents and teachers must both be properly trained for the diagnosis and treatment of children with ADHD(Barkley, 2020). ADHD is common and affects $2-18 \%$ of student children A survey of primary school professors in Iran revealed comparatively poor awareness of the causes of ADHD; they thought the explanation for the study was biological/genetic or parental spoil. Another two surveys of ADHD found similar results among school teachers in Thailand and South Texas(Alharbi, 2018). There was not enough information about ADHD even given by Makkah's school female teachers. Two studies in Saudi Arabia found that the incidence of ADHD was 11.6 percent and 16.3 percent. In contrast with hyperactivity among male students, a study done at the primary school in Dammam showed a higher prevalence of lack of attention. Teachers from primary schools have a big part to play in supporting children with ADHD and they can be the first to recognize a condition. Late intervention may result from a lack of knowledge amongst primary school teachers(Al Hamed, Taha, Sabra, \& Bella, 2008).

The student with ADHD can be distracted easily in the classroom and it is challenging to deal with such students. A need was observed in elementary schools of Punjab to develop an inventory for the identification and handling of ADHD children. In this instance, the role of the class teacher is highly critical. A well-trained teacher is capable of effective management of the classroom and it is like a hood that environment can be improved viably by characterization of ADHD along with clinical impairment(Ong, 2019).

According to Kostanjsek (2011), the ADHD indications are highly prominent in primary grades and have a strong foundation for the functioning of academic performance. ADHD children might exhibit different problems related to schools; for instance challenges in perusing direction, completion of assignments, and other psychological challenges(Dias et al., 2013). The ADHD children might reveal the worst relationship with peers, lower level of self-esteem, and delinquent behavior.

There is little information about ADHD in Pakistan, which means that teachers require comprehensive knowledge and experience in this area to support and understand these children to successfully change their behavior with effective approaches. Studies suggest that the intervention interaction facility improves teachers' awareness about ADHD(Mirza, Nisar, \& Ikram, 2017). A lack of awareness is evident across the Punjab and overall Pakistan about the intervention strategies of ADHD. On the other hand, a number of diagnosed children in primary schools of Punjab are prone to continuous increase(Bickenbach, Cieza, Rauch, \& Stucki, 2012). The student with ADHD can be distracted easily in the classroom and it is challenging to deal with such students. A need was observed in elementary schools of Punjab to develop an inventory for the identification and handling of ADHD children. In this instance, role of class teacher is highly critical. A well-trained teacher is capable for effective management of classroom and it is like hood that environment can be improved viably by characterization of ADHD along with clinical impairment. 
According to Kostanjsek (2011), the ADHD indications are highly prominent in primary grades and have a strong foundation for the functioning of academic performance. ADHD children might exhibit different problems related to schools; for instance, challenges in perusing direction, completion of assignments, and other psychological challenges. The ADHD children might reveal the worst relationship with peers, lower level of self-esteem, and delinquent behavior. A lack of awareness is evident across the Punjab and overall Pakistan about the intervention strategies of ADHD. On the other hand, a number of diagnosed children in primary schools of Punjab are prone to continuous increase(Hobday, 2015)

The major objectives of this research study are to determine the awareness level of primary school. The key research question of the study is what are the symptoms to identify ADHD students who are suffering from it and the perceived knowledge of primary school teachers in Punjab about ADHD and what extent the teachers know about the interventions for ADHD treatments? The identification of symptoms in ADHD students has a great significance which will be helpful for teachers in the future to assess students at admissions; for the development of educational intervention and improve the willingness of teachers for effective teaching and intervention. The findings of the study would also be helpful for teachers, schools, parents, and psychologists for designing effective strategies for effectively dealing with ADHD students. The finding will be significant for teachers to gaging their improved realization of characteristics, etiology and treatment of ADHD. For the concerned school district, the knowledge of teachers might lead to additional professional development for effectively managing this disorder. The findings provided the implication for devising behavioral strategies of management for dealing with ADHS students.

\section{Literature Review}

\subsection{ADHD in Primary School Students}

ADHD is a chronic neurological condition marked by hyperactivity and persistent inattention (Barkley, Murphy, \& Fischer, 2010). (Bolte, et al., 2018) said that the prevalence of ADHD was found to be 5.3 percent worldwide. In another report by NIMH, (2018) the global occurrence of ADHD was noted 3-5\% irrespective of age and gender. ADHD was found in all age groups but its development starts in early childhood stage and remains persistent throughout life(Tatlah,2014). A study conducted on primary school students by (Amiri, Shafiee-Kandjani, Fakhari, Golmirzaei, \& Rafi, 2013) evaluated that comorbidities in ADHD were presented in 62.5 percent of children. The author further explained about comorbidities of individuals as they were 17.2 percent enuresis, 26.7 percent phobias and 33.3 percent motor functioning. Moreover, another study used ICF to judge ADHD and found that occurrence is higher in female as compared to males (De Schipper, et al., 2015). McKinley L.A. and Stormont M. A. (2018), the study indicated that 5-7 percent of school-going children have ADHD(Abrahão, Elias, Zerbini, \& D'Ávila, 2020).

The rate of impulsivity, daydreaming, hyperactivity and inattentiveness are also common in Punjab in primary school students. It was noted from research that awareness about ADHD was less in teachers and parents. This may for the reason that the symptoms of neurological problems are almost the same; the common is mental retardation, learning disability and reduce motor functioning. A study by (McDougall, Wright, \& Rosenbaum, 2010) reported that the awareness level of $\mathrm{ADHD}$ in Karachi is about $44.6 \%$. In a primary 
hospital ADHD was found to be $34 \%$ in Pakistan. In the light of these empirical considerations, it has suggested that timely monitoring of the disease is necessary. For that analytical/ mentoring tools were used and discussed by researcher and scientist that could be helpful for teachers, parents, and guardians. Also, it was ascertained that analytic tools were effective and easily understandable by teachers and parents for the diagnosis of ADHD in children. From the literature review, it is analyzed that ACTeRS, Brown Attention Deficit Disorder Scales, Connors' Rating Scales, Copeland Symptom Checklist, DSM-V, Vanderbilt Assessment Scale, Wander Utah Rating Scale, and ICF were mostly used for the evaluation of ADHD(Matheis, 2020).

The tool that was found to be most effective for the evaluation of ADHD in primary school students are ICF. It is a conceptual framework model which described the health conditions in three perspectives which include participation, activities, body functions and structure. The ICF is the latest and advanced version of ICIDH and ICIDH-2 model presented by WHO. The ICIDH is the oldest version of ICF which monitored the ADHD in three domains which are impairment, disability, and handicap, While, the ICIDH-2 version contain domains of activity, participation, impairment and contextual disability. The final version was presented by WHO in 2001 called ICF. In the advance, version diagnosis moves from consequences to the classification of disease symptoms on the basis of functioning and disabilities. ICF was published officially in six different languages(Bölte et al., 2018). However, ICF checklist was approved by WHO in more than hundred countries as a diagnostic technique of health abilities and abnormalities in patients(Üstün, 2010).

The assessment tools and inventories for ADHD help to diagnose the disease and differentiate it from other diseases. It also priorities the goals of treatment as the specific criteria mentioned the abilities in an increase or a decreasing order. It became easy for parents or teachers to judge which one of the characters are more promoting and influencing ADHD. It was also observed from the literature review that the strengths and weakness of the students can also be evaluated from the ICF assessment tools. The the time period for the evaluation was minimized by use of ICF inventory(Tatlah,2015). There are many research studies, which used ICF checklist for the evaluation of ADHD. Furthermore, the development of inventory was also being discussed in reports and scientific papers. However, the questions or statements may differ in research but the basic conceptual framework was found to be same in all studies. (Karolinska, 2018) described that ICF model is considered as the best descriptive checklist for the assessment of ADHD and other autism disorders. Quality of life is considered as an important parameter in the ICF model scale(Cabral, Liu, \& Soares, 2020).

\section{Population \& Sample}

The population of the study was all the primary school students of public and private. All the primary students in public and private schools of Lahore. 20 primary school students were the assessable population for the study. The sample of the study was 440 students from the 20 schools of Lahore. A non-probability method called as purposive sampling was used for sampling.

\section{Development of Research Instrument}

The survey instrument was developed using the ICF checklist. It contained 84 questions in different 5 areas of psychological conditions of the students. The responses were evaluated based on the rating of five-point Likert scale. The instrument comprised of five subscales that indicated the 
symptoms for Attention, Hyperactive/Impulsive, Oppositional Defiant Disorder, Cognitive symptoms as well as psychosocial symptoms. On the other hand, for Qualitative interviews, open-ended questionnaire was developed for the encouragement of meaningful and full answers by utilizing the feeling and knowledge related to ADHD symptoms (Blumberg, Cooper, and Schindler, 2014). The developed instrument was distributed among 15 teachers and 10 parents for the pilot study. Results were satisfactory as respondents were able to understand the instrument easily. They also showed keen interest in the asked questions as they were informative for them as well.

\section{Data Collection \& Analysis}

The returned number of the questionnaire was 700/1000, from them, 99 questionnaires were incomplete as pages were missing. 161 questionnaires were not filled properly, as some options were marked on more than one option, or some options were not even filled. Those questionnaires were excluded from the data analysis. In the end accurate collected questionnaires were in total 440. The analysis of the collected data encompassed the statistical procedures performed to generate results and estimation of obtained information (Cline, 2011). The ADHD sufferers' participant's data of the preparatory phase were analyzed through an observational analysis and main findings were highlighted. Expert results were analyzed by identifying common information and then this information was presented in tables and figures. For the cross-sectional data result, most common symptoms from files were identified and a category was made, accordingly, the percentages of common symptoms were calculated through descriptive statistics. The results of consensus meetings, expert participation, and decisions were tabulated and common findings presented. Especially for the interactive session, the frequency and percentage of voting results were calculated. The final inventory was prepared and presented at the end of the data analysis.

\subsection{Demographic Analysis}

Table 1: Frequency Distribution of the Responses SYMPTOMS: Check the appropriate box

\begin{tabular}{|c|l|c|c|c|c|c|}
\hline $\begin{array}{c}\text { Sr. } \\
\text { No }\end{array}$ & Attention Symptoms & SD & D & UnD & A & SA \\
\hline 1 & $\begin{array}{l}\text { Fails to give close } \\
\text { attention to details of tasks } \\
\text { and activities }\end{array}$ & o(0\%) & o(0\%) & o(0\%) & $440(100 \%)$ & o(o\%) \\
\hline 2 & $\begin{array}{l}\text { Could not sustain } \\
\text { attention to given tasks or } \\
\text { activities }\end{array}$ & $189(43 \%)$ & $112(25.5 \%)$ & $70(15.9 \%)$ & $44(10 \%)$ & $25(5.7 \%)$ \\
\hline 3 & $\begin{array}{l}\text { Does not put focused } \\
\text { attention on class work }\end{array}$ & $178(40.5 \%)$ & $87(19.8 \%)$ & $68(15.5 \%)$ & $62(14.1 \%)$ & $45(10.2 \%)$ \\
\hline 4 & $\begin{array}{l}\text { Feels difficulty focusing on } \\
\text { one task to complete it at a } \\
\text { time. }\end{array}$ & $170(38.6 \%)$ & $92(20.9 \%)$ & $72(16.4 \%)$ & $56(12.7 \%)$ & $50(11.4 \%)$ \\
\hline 5 & $\begin{array}{l}\text { Has short concentration } \\
\text { span }\end{array}$ & $162(36.8 \%)$ & $99(22.5 \%)$ & $72(16.4 \%)$ & $68(15.5 \%)$ & $39(8.9 \%)$ \\
\hline 6 & Easily distracted & $162(36.8 \%)$ & $91(20.7 \%)$ & $87(19.8 \%)$ & $68(15.5 \%)$ & $32(7.3 \%)$ \\
\hline
\end{tabular}




\begin{tabular}{|c|c|c|c|c|c|c|}
\hline 7 & $\begin{array}{l}\text { Feels difficulty in } \\
\text { understanding } \\
\text { instructions }\end{array}$ & $161(36.6 \%)$ & $100(22.7 \%)$ & $95(21.6 \%)$ & $53(12 \%)$ & $31(7 \%)$ \\
\hline 8 & $\begin{array}{l}\text { Fails to finish assigned } \\
\text { task or activity on time }\end{array}$ & $151(34.4 \%)$ & $118(26.8 \%)$ & $78(17.7 \%)$ & $59(13.4 \%)$ & $34(7 \cdot 7 \%)$ \\
\hline 9 & Does not like worksheets. & $156(35.5 \%)$ & $102(23.3 \%)$ & $90(20.5 \%)$ & $61(13.9 \%)$ & $31(7 \%)$ \\
\hline 10 & $\begin{array}{l}\text { Does not like to follow } \\
\text { written instruction }\end{array}$ & $137(31.1 \%)$ & $95(21.6 \%)$ & $\begin{array}{c}106(24.1 \% \\
)\end{array}$ & $68(15 \cdot 5 \%)$ & $34(7.7 \%)$ \\
\hline 11 & $\begin{array}{l}\text { Performs better with given } \\
\text { fewer words instructions. }\end{array}$ & $137(31.1 \%)$ & $85(19 \cdot 3 \%)$ & $97(22 \%)$ & $78(17.7 \%)$ & $43(9.8 \%)$ \\
\hline 12 & $\begin{array}{l}\text { Feels difficulty solving } \\
\text { simple math problems }\end{array}$ & $124(28.2 \%)$ & $97(22 \%)$ & $96(21.8 \%)$ & $74(16.8 \%)$ & $49(11.1 \%)$ \\
\hline 13 & $\begin{array}{l}\text { Does not seem to listen } \\
\text { when spoken to him } \\
\text { directly }\end{array}$ & $125(28.4 \%)$ & $92(20.9 \%)$ & $\begin{array}{c}112(25 \cdot 5 \% \\
)\end{array}$ & $53(12 \%)$ & $58(13.2 \%)$ \\
\hline 14 & Makes careless mistakes & $124(28.2 \%)$ & $103(23.4 \%)$ & $85(19 \cdot 3 \%)$ & $70(15.9 \%)$ & $58(13.2 \%)$ \\
\hline 15 & Loose things & $135(30.7 \%)$ & $97(22 \%)$ & $97(22 \%)$ & $66(15 \%)$ & $45(10.2 \%)$ \\
\hline 16 & $\begin{array}{l}\text { Could not explain back } \\
\text { his/her understanding of } \\
\text { the given instructions }\end{array}$ & $135(30.7 \%)$ & $119(27 \%)$ & $86(19 \cdot 5 \%)$ & $62(14.1 \%)$ & $38(8.6 \%)$ \\
\hline 17 & Poor handwriting & $132(30 \%)$ & $110(25 \%)$ & $88(20 \%)$ & $58(13.2 \%)$ & $52(11.8 \%)$ \\
\hline 18 & $\begin{array}{l}\text { Feels difficulty in } \\
\text { organizing tasks and } \\
\text { activities }\end{array}$ & $139(31.6 \%)$ & $107(24 \cdot 3 \%)$ & $93(21.1 \%)$ & $53(12 \%)$ & $48(10.9 \%)$ \\
\hline 19 & $\begin{array}{l}\text { Avoids, dislikes or is } \\
\text { reluctant to engage in } \\
\text { tasks that require } \\
\text { sustained mental effort }\end{array}$ & $136(30.9 \%)$ & $100(22.7 \%)$ & $92(20.9 \%)$ & $72(16.4 \%)$ & $40(9.1 \%)$ \\
\hline 20 & $\begin{array}{l}\text { Avoids tasks requiring } \\
\text { long mental focus. }\end{array}$ & $123(28 \%)$ & $104(23.6 \%)$ & $89(20.2 \%)$ & $70(15 \cdot 9 \%)$ & $54(12.3 \%)$ \\
\hline 21 & $\begin{array}{l}\text { Fails to complete longer } \\
\text { tasks. }\end{array}$ & $226(51.4 \%)$ & $81(18.4 \%)$ & $58(13.2 \%)$ & $44(10 \%)$ & $31(7 \%)$ \\
\hline 22 & $\begin{array}{l}\text { Requires more time to } \\
\text { complete tasks as } \\
\text { compared to normal } \\
\text { students. }\end{array}$ & $116(26.4 \%)$ & $153(34.8 \%)$ & $68(15 \cdot 5 \%)$ & $53(12 \%)$ & $49(11.1 \%)$ \\
\hline 23 & $\begin{array}{l}\text { Afraid to try new things } \\
\text { due to fear of making } \\
\text { mistakes }\end{array}$ & $121(27.5 \%)$ & $101(23 \%)$ & $95(21.6 \%)$ & $63(14 \cdot 3 \%)$ & $60(13.6 \%)$ \\
\hline 24 & $\begin{array}{l}\text { Fails to achieve } \\
\text { performance goals set for } \\
\text { normal students }\end{array}$ & $116(26.4 \%)$ & $116(26.4 \%)$ & $91(20.7 \%)$ & $79(18 \%)$ & $38(8.6 \%)$ \\
\hline 25 & $\begin{array}{l}\text { Face difficulty in } \\
\text { organizing things }\end{array}$ & $124(28.2 \%)$ & $99(22.5 \%)$ & $94(21.4 \%)$ & $56(12.7 \%)$ & $67(15.2 \%)$ \\
\hline 26 & $\begin{array}{l}\text { Feels difficulty in } \\
\text { concentrating }\end{array}$ & $112(25 \cdot 5 \%)$ & $105(23.9 \%)$ & $94(21.4 \%)$ & $66(15 \%)$ & $63(14 \cdot 3 \%)$ \\
\hline
\end{tabular}


Table 2: Frequency Distribution of the Responses Hyperactive/Impulsive 314.01

\begin{tabular}{|c|c|c|c|c|c|c|}
\hline $\begin{array}{l}\text { Sr. } \\
\text { No }\end{array}$ & $\begin{array}{l}\text { Hyperactive/Impulsive } \\
314.01\end{array}$ & SD & $\mathbf{D}$ & UnD & A & SA \\
\hline 1 & $\begin{array}{l}\text { Often fidgets with hands } \\
\text { or feet }\end{array}$ & $\mathrm{o}(\mathrm{O} \%)$ & $\mathrm{o}(\mathrm{O} \%)$ & $\mathrm{o}(\mathrm{O} \%)$ & $440(100 \%)$ & $\mathrm{o}(\mathrm{O} \%)$ \\
\hline 2 & $\begin{array}{l}\text { Fidgets and leave seat } \\
\text { when sitting still is } \\
\text { expected }\end{array}$ & $90(20.5 \%)$ & $165(37 \cdot 5 \%)$ & $94(21.4 \%)$ & $70(15 \cdot 9 \%)$ & $21(4.8 \%)$ \\
\hline 3 & $\begin{array}{l}\text { Does not remain in seat } \\
\text { during given activity }\end{array}$ & $114(25.9 \%)$ & $98(22.3 \%)$ & $127(28.9 \%)$ & $76(17 \cdot 3 \%)$ & $25(5 \cdot 7 \%)$ \\
\hline 4 & $\begin{array}{l}\text { Absents from class } \\
\text { without permission }\end{array}$ & $109(24.8 \%)$ & $117(26.6 \%)$ & $91(20.7 \%)$ & $78(17.7 \%)$ & $45(10.2 \%)$ \\
\hline 5 & $\begin{array}{l}\text { Leaves group or } \\
\text { classroom when } \\
\text { supposed to stay seated. }\end{array}$ & $126(28.6 \%)$ & $113(25 \cdot 7 \%)$ & $106(24.1 \%)$ & $47(10.7 \%)$ & $48(10.9 \%)$ \\
\hline 6 & Feels restless & $99(22.5 \%)$ & $140(31.8 \%)$ & $102(23.2 \%)$ & $63(14 \cdot 3 \%)$ & $36(8.2 \%)$ \\
\hline 7 & Always on the go & $98(22.3 \%)$ & $123(28 \%)$ & $116(26.5 \%)$ & $57(13 \%)$ & $46(10.5 \%)$ \\
\hline 8 & $\begin{array}{l}\text { Runs about or climbs } \\
\text { excessively }\end{array}$ & $106(24.1 \%)$ & $114(25 \cdot 9 \%)$ & $124(25 \cdot 9 \%)$ & $54(12.3 \%)$ & $42(9 \cdot 5 \%)$ \\
\hline 9 & $\begin{array}{l}\text { Demonstrates agitated } \\
\text { attitude if dislikes the } \\
\text { adults instruction } \\
\text { /request }\end{array}$ & $117(26.6 \%)$ & $117(26.6 \%)$ & $112(25 \cdot 5 \%)$ & $61(13.9 \%)$ & $33(7 \cdot 5 \%)$ \\
\hline 10 & $\begin{array}{l}\text { Does not finish assigned } \\
\text { class work. }\end{array}$ & $117(26.6 \%)$ & $126(28.6 \%)$ & $100(22.7 \%)$ & $59(13.4 \%)$ & $38(8.6 \%)$ \\
\hline 11 & $\begin{array}{l}\text { Feels difficulty in taking } \\
\text { turn }\end{array}$ & $119(27 \%)$ & $120(27 \cdot 3 \%)$ & $104(23.6 \%)$ & $64(14 \cdot 5 \%)$ & $33(7 \cdot 5 \%)$ \\
\hline 12 & $\begin{array}{l}\text { Interrupts or intrudes } \\
\text { others (e.g., butts into } \\
\text { conversations or games) }\end{array}$ & $89(20.2 \%)$ & $123(28 \%)$ & $121(27 \cdot 5 \%)$ & $73(16.6 \%)$ & $34(7 \cdot 7 \%)$ \\
\hline 13 & focusing on any one task & $108(24.5 \%)$ & $113(25 \cdot 7 \%)$ & $103(23.4 \%)$ & $69(15.7 \%)$ & $47(10.7 \%)$ \\
\hline 14 & $\begin{array}{l}\text { Does not like working in } \\
\text { groups. }\end{array}$ & $92(20.9 \%)$ & $131(29.8 \%)$ & $115(26.1 \%)$ & $63(14 \cdot 3 \%)$ & $63(14 \cdot 3 \%)$ \\
\hline 15 & $\begin{array}{l}\text { Prefers to perform } \\
\text { activity/work alone }\end{array}$ & $114(25 \cdot 9 \%)$ & $103(23.4 \%)$ & $101(23 \%)$ & $75(17 \%)$ & $47(10.7 \%)$ \\
\hline 16 & Talks excessively & $94(21.4 \%)$ & 135(30.7\%) & $90(20.5 \%)$ & $69(15.7 \%)$ & $52(11.8 \%)$ \\
\hline 17 & $\begin{array}{l}\text { Feels difficulty in doing } \\
\text { things quietly }\end{array}$ & $110(25 \%)$ & $120(27 \cdot 3 \%)$ & $106(24.1 \%)$ & $61(13 \cdot 9 \%)$ & $43(9.8 \%)$ \\
\hline 18 & $\begin{array}{l}\text { Blurts answers before } \\
\text { questions have been } \\
\text { completed }\end{array}$ & $104(23.6 \%)$ & $116(26.4 \%)$ & $103(23.4 \%)$ & $69(15 \cdot 7 \%)$ & $48(10.9 \%)$ \\
\hline 19 & $\begin{array}{l}\text { Does not understand the } \\
\text { cause and effect of }\end{array}$ & $109(24.8 \%)$ & $97(22 \%)$ & $114(25.9 \%)$ & $65(14.8 \%)$ & $55(12.5 \%)$ \\
\hline
\end{tabular}




\begin{tabular}{|c|l|l|l|l|l|l|}
\hline & behavior & & & & & \\
\hline 20 & $\begin{array}{l}\text { Likes doodling or play } \\
\text { with clay, paper clips, or } \\
\text { pipe cleaners } \\
\text { while waiting or listening } \\
\text { to instructions }\end{array}$ & $110(25 \%)$ & $116(26.4 \%)$ & $99(22.5 \%)$ & $69(15 \cdot 7 \%)$ & $46(10.5 \%)$ \\
\hline 21 & $\begin{array}{l}\text { Demonstrates repetitive } \\
\text { motor behaviors (e.g., } \\
\text { table-tapping) or playing } \\
\text { with objects. }\end{array}$ & $91(20.7 \%)$ & $116(26.4 \%)$ & $97(22 \%)$ & $81(18.4 \%)$ & $55(12.5 \%)$ \\
\hline
\end{tabular}

Table 3: Frequency Distribution of the Responses

Oppositional Defiant Disorder 313.81 (a pattern of hostile, disobedient, and defiant behaviors directed at adults or other authority figures)

\begin{tabular}{|c|c|c|c|c|c|c|}
\hline $\begin{array}{l}\text { Sr. } \\
\text { No }\end{array}$ & $\begin{array}{l}\text { Oppositional } \\
\text { Defiant Disorder }\end{array}$ & SD & $\mathbf{D}$ & UnD & A & SA \\
\hline 1 & Fighting & $167(38 \%)$ & $91(20.7 \%)$ & $96(21.8 \%)$ & $57(13 \%)$ & $29(6.6 \%)$ \\
\hline 2 & Easily Loses temper & $91(20.7 \%)$ & $114(25.9 \%)$ & $129(29 \cdot 3 \%)$ & $73(16.6 \%)$ & $33(7 \cdot 5 \%)$ \\
\hline 3 & $\begin{array}{l}\text { Argues with peers } \\
\text { and adults }\end{array}$ & $218(49 \cdot 5 \%)$ & $84(19.1 \%)$ & $71(16.1 \%)$ & $46(10.5 \%)$ & $21(4.8 \%)$ \\
\hline 4 & $\begin{array}{l}\text { Refuses to follow } \\
\text { rules }\end{array}$ & $105(23.9 \%)$ & $184(41.8 \%)$ & $79(18 \%)$ & $52(11.8 \%)$ & $20(4.5 \%)$ \\
\hline 5 & $\begin{array}{l}\text { Deliberately acting in } \\
\text { a way that annoys } \\
\text { others }\end{array}$ & $127(28.9 \%)$ & $86(19.5 \%)$ & $135(30.7 \%)$ & $63(14 \cdot 3 \%)$ & $29(6.6 \%)$ \\
\hline 6 & $\begin{array}{l}\text { Blames others for } \\
\text { his/ her mistakes or } \\
\text { misbehavior }\end{array}$ & $100(22.7 \%)$ & $125(28.4 \%)$ & $90(20.5 \%)$ & $79(18 \%)$ & $46(10.5 \%)$ \\
\hline 7 & $\begin{array}{l}\text { Blatant hostility } \\
\text { towards others }\end{array}$ & $112(25 \cdot 5 \%)$ & $100(22.7 \%)$ & $111(25.2 \%)$ & $53(12 \%)$ & $64(14.5 \%)$ \\
\hline 8 & $\begin{array}{l}\text { Physically cruel to } \\
\text { people }\end{array}$ & $98(22.3 \%)$ & $111(25.2 \%)$ & $110(25 \%)$ & $74(16.8 \%)$ & $47(10.7 \%)$ \\
\hline 9 & $\begin{array}{l}\text { Deliberately destroys } \\
\text { others }{ }^{\text {ee }} \text { property }\end{array}$ & $105(23.9 \%)$ & $100(22.7 \%)$ & $144(32.7 \%)$ & $51(11.6 \%)$ & $40(9.1 \%)$ \\
\hline 10 & $\begin{array}{l}\text { Angry, resentful and } \\
\text { unwilling to } \\
\text { compromise }\end{array}$ & $100(22.7 \%)$ & $129(29 \cdot 3 \%)$ & $111(25.2 \%)$ & $66(15 \%)$ & $34(7 \cdot 7 \%)$ \\
\hline 11 & $\begin{array}{l}\text { Easily annoyed by } \\
\text { others }\end{array}$ & $118(26.8 \%)$ & $107(24 \cdot 3 \%)$ & $102(23.2 \%)$ & $73(16.6 \%)$ & $40(9.1 \%)$ \\
\hline 12 & $\begin{array}{l}\text { Willingly destroying } \\
\text { friendships }\end{array}$ & $95(21.6 \%)$ & $131(29.8 \%)$ & $109(24.8 \%)$ & $66(15 \%)$ & $39(8.9 \%)$ \\
\hline 13 & $\begin{array}{l}\text { Spiteful and seeking } \\
\text { revenge }\end{array}$ & $109(24.8 \%)$ & $93(21.1 \%)$ & $127(28.9 \%)$ & $72(16.4 \%)$ & $39(8.9 \%)$ \\
\hline 14 & $\begin{array}{l}\text { Blatant and repeated } \\
\text { disobedience }\end{array}$ & $97(22 \%)$ & $92(20.9 \%)$ & $116(26.4 \%)$ & $90(20.5 \%)$ & $45(10.2 \%)$ \\
\hline
\end{tabular}




\begin{tabular}{|c|l|c|c|c|c|c|}
\hline 15 & $\begin{array}{l}\text { Bullies, threatens, or } \\
\text { intimidates others }\end{array}$ & $100(22.7 \%)$ & $102(23.2 \%)$ & $108(24.5 \%)$ & $77(17.5 \%)$ & $53(12 \%)$ \\
\hline 16 & $\begin{array}{l}\text { Initiates physical } \\
\text { fights }\end{array}$ & $94(21.4 \%)$ & $111(25.2 \%)$ & $108(24.5 \%)$ & $82(18.6 \%)$ & $45(10.2 \%)$ \\
\hline 17 & $\begin{array}{l}\text { Makes inappropriate } \\
\text { verbalizations (e.g., } \\
\text { nonsense noises). }\end{array}$ & $81(18.4 \%)$ & $91(20.7 \%)$ & $153(34.8 \%)$ & $65(14.8 \%)$ & $50(11.4 \%)$ \\
\hline 18 & $\begin{array}{l}\text { Lies to obtain goods } \\
\text { for favors or to avoid } \\
\text { obligations (i.e., } \\
\text { "cons" others) }\end{array}$ & $82(18.6 \%)$ & $76(17.3 \%)$ & $168(38.2 \%)$ & $70(15.9 \%)$ & $43(9.8 \%)$ \\
\hline
\end{tabular}

Table 4: Frequency Distribution of the Responses Cognitive Symptoms:

\begin{tabular}{|c|l|c|c|c|c|c|}
\hline $\begin{array}{c}\text { Sr. } \\
\text { No }\end{array}$ & lognitive Symptoms: & SD & D & UnD & A & SA \\
\hline 1 & Frequent frustration & $182(41.4 \%)$ & $74(16.8 \%)$ & $93(21.1 \%)$ & $61(13.9 \%)$ & $30(6.8 \%)$ \\
\hline 2 & Feels worthless or inferior & $83(18.9 \%)$ & $145(33 \%)$ & $120(27.3 \%)$ & $62(14.1 \%)$ & $30(6.8 \%)$ \\
\hline 3 & $\begin{array}{l}\text { Failure to "think before } \\
\text { speaking" }\end{array}$ & $107(24.3 \%)$ & $81(18.4 \%)$ & $141(32 \%)$ & $78(17.7 \%)$ & $33(7.5 \%)$ \\
\hline 4 & $\begin{array}{l}\text { Easily distracted by } \\
\text { extraneous stimuli }\end{array}$ & $85(19.3 \%)$ & $110(25 \%)$ & $95(25.6 \%)$ & $(\%)$ & $(\%)$ \\
\hline 5 & $\begin{array}{l}\text { Loses things necessary for } \\
\text { tasks or activities (school } \\
\text { assignments, pencils or } \\
\text { books) }\end{array}$ & $98(22.3 \%)$ & $105(23.9 \%)$ & $123(28 \%)$ & $49(11.1 \%)$ & $65(14.8 \%)$ \\
\hline 6 & $\begin{array}{l}\text { Has difficulty organizing } \\
\text { tasks and activities }\end{array}$ & $71(16.1 \%)$ & $94(21.4 \%)$ & $131(29.8 \%)$ & $82(18.6 \%)$ & $62(14.1 \%)$ \\
\hline
\end{tabular}

Table 5: Frequency Distribution of the Responses Psychosocial Symptoms:

\begin{tabular}{|c|l|c|c|c|c|c|}
\hline $\begin{array}{l}\text { Sr. } \\
\text { No }\end{array}$ & $\begin{array}{l}\text { Psychosocial } \\
\text { Symptoms: }\end{array}$ & SD & D & UnD & A & SA \\
\hline 1 & $\begin{array}{l}\text { Difficulty making } \\
\text { friends }\end{array}$ & $173(39.3 \%)$ & $90(20.5 \%)$ & $83(18.9 \%)$ & $60(13.6 \%)$ & $34(7.7 \%)$ \\
\hline 2 & Persistent negativity & $84(19.1 \%)$ & $173(39.3 \%)$ & $103(23.4 \%)$ & $56(12.7 \%)$ & $24(5.5 \%)$ \\
\hline 3 & Consistent feelings of & $96(21.8 \%)$ & $102(23.2 \%)$ & $139(31.6 \%)$ & $71(16.1 \%)$ & $32(7.3 \%)$ \\
\hline
\end{tabular}




\begin{tabular}{|c|c|c|c|c|c|c|}
\hline & annoyance & & & & & \\
\hline 4 & Loss of self-esteem & $76(17 \cdot 3 \%)$ & $141(32 \%)$ & $98(22.3 \%)$ & $72(16.4 \%)$ & $53(12 \%)$ \\
\hline 5 & $\begin{array}{l}\text { Feels lonely, } \\
\text { unwanted, or } \\
\text { unloved: complains } \\
\text { that "no one loves } \\
\text { him/her" }\end{array}$ & $102(23.2 \%)$ & $104(23.6 \%)$ & $114(25 \cdot 9 \%)$ & $67(15.2 \%)$ & $53(12 \%)$ \\
\hline 6 & $\begin{array}{l}\text { Sad, unhappy, or } \\
\text { depressed }\end{array}$ & $81(18.4 \%)$ & $120(27 \cdot 3 \%)$ & $121(27 \cdot 5 \%)$ & $67(15.2 \%)$ & $51(11.6 \%)$ \\
\hline 7 & $\begin{array}{l}\text { Does not like to } \\
\text { interact with general } \\
\text { people }\end{array}$ & $86(19.5 \%)$ & $114(25 \cdot 9 \%)$ & $124(28.2 \%)$ & $69(15 \cdot 7 \%)$ & $47(10.7 \%)$ \\
\hline 8 & $\begin{array}{l}\text { Does not follow } \\
\text { instructions }\end{array}$ & $81(18.4 \%)$ & $119(27 \%)$ & $120(27 \cdot 3 \%)$ & $67(15.2 \%)$ & $53(12 \%)$ \\
\hline 9 & $\begin{array}{l}\text { Steels items of } \\
\text { nontrivial value }\end{array}$ & $103(23.4 \%)$ & $104(23.6 \%)$ & $113(25 \cdot 7 \%)$ & $75(17 \%)$ & $45(10.2 \%)$ \\
\hline 10 & $\begin{array}{l}\text { Likes appreciation } \\
\text { and praise Strongly } \\
\text { Agree }\end{array}$ & $82(18.6 \%)$ & $115(\%)$ & $113(25 \cdot 7 \%)$ & $69(15 \cdot 7 \%)$ & $61(13.9 \%)$ \\
\hline 11 & $\begin{array}{l}\text { Likes activity-based } \\
\text { task over rote } \\
\text { learning. }\end{array}$ & $97(22 \%)$ & $99(22.5 \%)$ & $112(25 \cdot 5 \%)$ & $74(16.8 \%)$ & $58(13.2 \%)$ \\
\hline 12 & $\begin{array}{l}\text { Feels difficulty in } \\
\text { following school's } \\
\text { rules }\end{array}$ & $83(18.9 \%)$ & $117(26.6 \%)$ & $102(23.2 \%)$ & $72(16.4 \%)$ & $66(15 \%)$ \\
\hline
\end{tabular}

\section{Discussion}

In the case of the social environment, ADHD children are continuously facing challenges. Because of disruptive attitude and behavior, rejection of peer is highly prevalent for children having ADHD disorder. Such negative attributes might not end in childhood and the pattern of disruptive behavior in early school years can increase the dramatic risk for antisocial behavior later. Because of pervasive and disruptive ADHD nature, effectual treatments are required (Bölte, et al 2014).

The resource constraints can plague the mental service of a child in the same manner as required by the mental service of an adult. The mental health of child service can be governed utilizing manifold factors. The extent of the convention of referral, relations with specialists, physicians, and teachers are considered a few vital factors of governance. Whereas, it is customary to possess referral from schools in a well-established system of health care, a failure is observed in evaluation of referral from a knowledge base of Pakistani school system. The main rationalization is related to the lack of awareness about mental health in Punjabi school teachers. The other factors are based on the absence of health care style and enclosed stigma towards emotional and mental disorders and deficiency of adequate interaction with the individual resource (Sharma, \& Inamdar, 2013). In brief, psychiatry services of the child are based on multiple disciplines, liaises among clinical psychologist, teacher, and parent. In the same manner, the communication 
with a teacher is of paramount significance and identical realization is required regarding the behavioral management principles.

\section{Recommendations}

1. Providing awareness to teachers, parents and other family members is highly recommended that Parents should establish teaching skills to provoke positive behavior among children by using different methods.

2. The study recommends that a longitudinal study is required to address the topic further for the facilitation of children with ADHD.

3. The in-service school teachers should be provided the opportunities for continuous professional development that teachers could create positive, open an environment where students could explain their viewpoint about stress and mental health problems; which will enable the teacher to approach valuable strategies and resources for supporting the ADHD students.

\section{References}

Abrahão, A. L. B., Elias, L. C. d. S., Zerbini, T., \& D'Ávila, K. M. G. (2020). Attention Deficit Hyperactivity Disorder, educational inclusion and Training, Development and Education: an integrative review. Revista Psicologia Organizações e Trabalho, 20(2), 1025-1032.

Al Hamed, J. H., Taha, A. Z., Sabra, A. A., \& Bella, H. (2008). Attention deficit hyperactivity disorder (ADHD) among male primary school children in Dammam, Saudi Arabia: Prevalence and associated factors. J Egypt Public Health Assoc, 83(3-4), 165-182.

Alfageer, H. H., Aldawodi, M. D., Al Queflie, S. A., Masud, N., Al Harthy, N. A., Alogayyel, N., Qureshi, S. (2018). Knowledge and attitude of male primary school teachers about attention deficit and hyperactivity disorder in Riyadh, Saudi Arabia. Journal of Natural Science, Biology and Medicine, $9(2), 257$.

Alharbi, R. (2018). Attention Deficit Hyperactivity Disorder (ADHD) Discourses in Saudi Arabia. Université d'Ottawa/University of Ottawa.

Barkley, R. A. (2020). Taking charge of ADHD: The complete, authoritative guide for parents: Guilford Publications.

Bickenbach, J., Cieza, A., Rauch, A., \& Stucki, G. (2012). ICF core sets: manual for clinical practice for the ICF research branch, in cooperation with the WHO collaborating centre for the family of international classifications in Germany (DIMDI): Hogrefe Publishing.

Bölte, S., Mahdi, S., Coghill, D., Gau, S. S.F., Granlund, M., Holtmann, M., Segerer, W. (2018). Standardised assessment of functioning in ADHD: consensus on the ICF Core Sets for ADHD. European child \& adolescent psychiatry, 27(10), 1261-1281.

Cabral, M. D. I., Liu, S., \& Soares, N. (2020). Attention-deficit/hyperactivity disorder: diagnostic criteria, epidemiology, risk factors and evaluation in youth. Translational pediatrics, 9(Suppl 1), S104.

Dias, T. G. C., Kieling, C., Graeff-Martins, A. S., Moriyama, T. S., Rohde, L. A., \& Polanczyk, G. V. (2013). Developments and challenges in the diagnosis and treatment of ADHD. Brazilian Journal of Psychiatry, 35, S40-S50.

Drechsler, R., Brem, S., Brandeis, D., Grünblatt, E., Berger, G., \& Walitza, S. (2020). ADHD: Current Concepts and Treatments in Children and Adolescents. Neuropediatrics, 51(5), 315.

Hobday, D. (2015). Communicating With Teachers: Perspectives From Parents of Children With and 
Without Exceptionalities. University of Saskatchewan.

Matheis, M. (2020). Assessment and Diagnosis of Attention-Deficit/Hyperactivity Disorder in Individuals with Intellectual Disability Handbook of Dual Diagnosis (pp. 267-283): Springer.

Mirza, N., Nisar, N., \& Ikram, Z. (2017). Knowledge, attitude \& practices towards attention deficit hyperactivity disorder among private elementary school teachers of Karachi, Pakistan. Journal of the Dow University of Health Sciences (JDUHS), 11(1), 11-17.

Ong, C. L. G. (2019). Maintenance of self-monitoring attention intervention for students with attention deficit/hyperactivity disorder.

Tatlah, I. A. (2015). Effect of leadership behaviour and school organizational health on students'achievement. Lahore: (Unpublished Doctoral Thesis) University of Management and Technology, Lahore.

Tatlah, I. A., Iqbal, M. Z., Amin, M., \& Quraishi, U. Q. (2014). Effect of leadership behaviour of principals on students' academic achievement at secondary level: A comparison of leaders and teachers perceptions. Journal of Research and Reflections in Education, 1-12. 